\title{
Factors Affecting Rural Land Prices In An Urbanizing Area\#
}

\author{
John E. Reynolds and Devin L. Tower*
}

Urban growth in many areas of the South has been accompanied by changes in land use and increases in rural land prices in the surrounding areas. The conversion of agricultural land to a nonagricultural use in an urbanizing area appears to have had a marked affect on rural land prices.

Rural land prices vary widely from one area to another. For example, in 1974 the county average value of farmland and buildings in the Southeast ranged from a low of $\$ 108$ per acre in Cullman County, Alabama to a high of $\$ 3,691$ per acre in Dade County, Florida [16]. In general the counties with low rural land prices were located in rural areas away from metropolitan areas while counties with high rural land prices were located near heavily populated areas suggesting that an urbanizing area exerts an important impact on rural land prices.

The demand for land arises from the various direct and derived uses to which land may be put. Direct demand for land results when land is used for consumption, such as for residential sites or recreational purposes. However, much of the demand for land is derived from the productive potential of land, its location or other advantages rather than the land itself. The demand for land is the sum of the various direct and derived demands for land.

If the demand for land increases without corresponding increases in the supply of land, the price of land will increase. In recent years the demand for rural land appears to have increased substantially without an offsetting increase in the supply of land and has resulted in rural land prices rising to unprecedented levels.

The nonagricultural demand for rural land has become increasingly important in the competition for rural land. The location of rural land with respect to metropolitan areas and transportation routes appears to have been an important determinant of rural land prices [2]. Increases in population and per capita income have increased the nonagricultural demand for land. These increases in population and incomes have not only increased the derived demand for rural land through the increased demand for agricultural products, but it has also increased the direct demand for rural land for residential, recreational and other uses. In addition, improvements and expansions in the transportation network

\footnotetext{
\#Paper presented at the Southern Regional Science Association meeting, April 13-15, 1980, Savannah, Georgia. Florida Agricultural Experimental Stations Journal Series No. 2495.

* Professor, Department of Food and Resource Economics, Univeraity of Florida, and Mortgage Loan Officer, Barnett Banks of Volusia County, Daytona Beach, Florida, respectively.
} 
have made rural land more accessible to urban residents and resulted in increased competition between agricultural and nonagricultural uses for rural land. The objective of this paper is to examine the impact of physical and locational characteristics of property on rural land prices in an urbanizing area.

\section{THE STUDY AREA}

To identify and estimate the effect of different factors affecting rural land prices a six county area in East Central Florida was selected. The study area was comprised of Lake, Orange, Osceola, Seminole, Volusia and Brevard Counties which constitute Planning District 6 in Florida (Figure 1). Orlando is the major metropolitan area and is located in Orange County close to the center of the study area. This area has experienced considerable growth in population and commercial activity, yet many parts of the area are still rural in nature. The area has a wide range of data representing the characteristics affecting rural land prices in Florida.

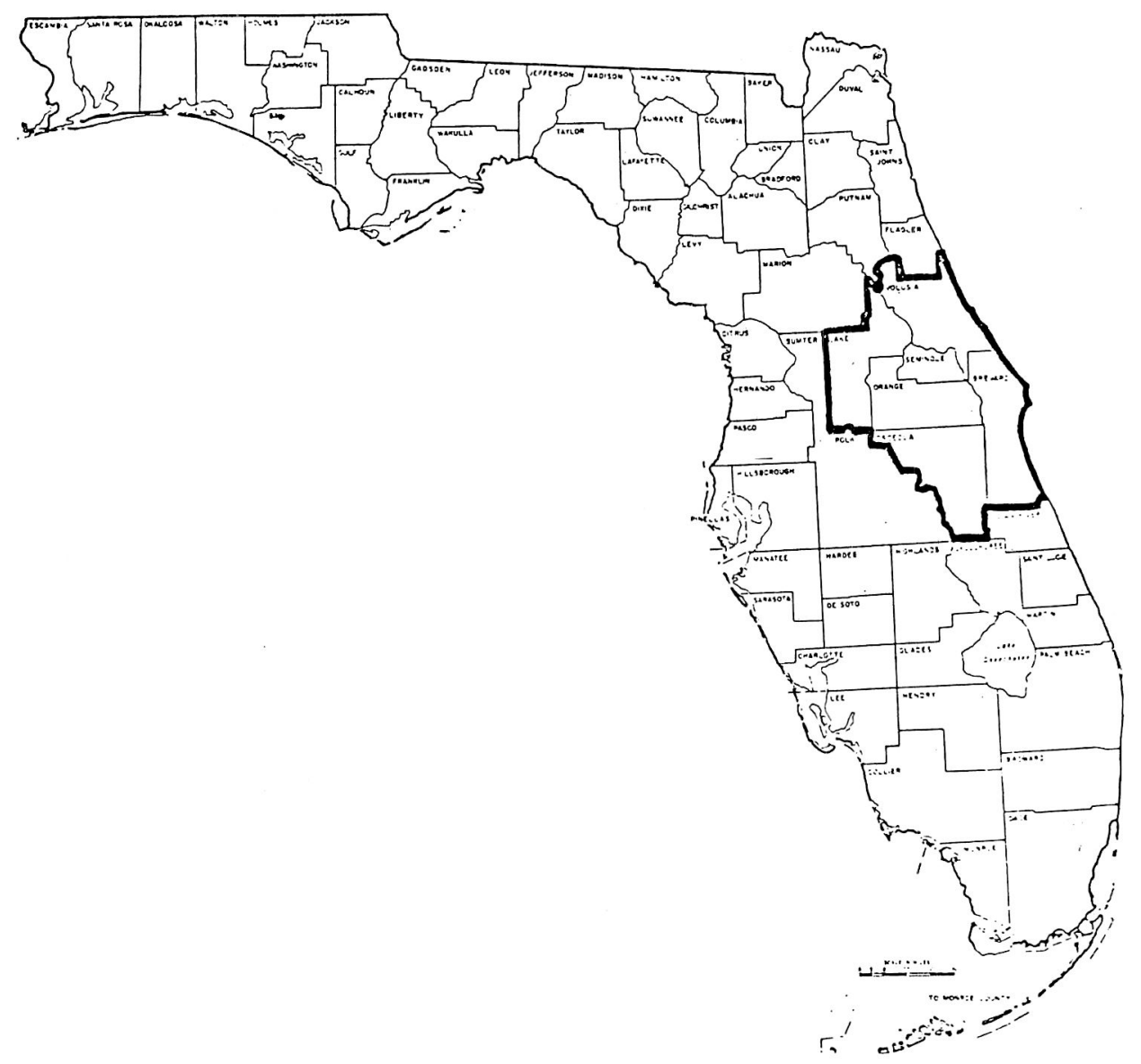

Figure 1. The study area in East Central Florida. 
The population of the study area was $1,171,175$ in 1977 [14]. The population density ranged from an average of 466.5 people per square mile in Orange County to a low of 27.9 people per square mile in Osceola County. The agricultural use of rural land and location with respect to commercial development are also important characteristics affecting variation in rural land prices. Lake, Orange and South Brevard Counties have substantial acreages devoted to citrus production. Ornamentals and nursery products are also produced in Orange and Lake Counties. Commercial development, including Disney World in Orange County and the Kennedy Space Center in Brevard County, also affects the nonagricultural demand for rural land.

\section{CONCEPTUAL MODEL}

Data were obtained on rural land sales in the six-county study area from the Federal Land Bank. The data consisted of information on the sale of 252 tracts of rural land and included location, the physical characteristics of each tract, the value of buildings and characteristics concerning the financial terms. The following general model was formulated to estimate the impact of these factors on rural land prices:

where

$$
P=f(L U, V B, \text { LOC, S })
$$

$$
\begin{aligned}
\mathrm{P} & =\text { price per acre for each tract } \\
\mathrm{LU} & =\text { land use variables } \\
\mathrm{VB} & =\text { value of buildings per acre, } \\
\mathrm{LOC} & =\text { locational variables measured in distance, and } \\
\mathrm{S} & =\text { size of each tract in acres. }
\end{aligned}
$$

Theoretically, the value of land should equal the sum of the future returns to land discounted back to the present. Previous studies have established that a strong positive relationship exists between farm income and rural land prices $[6,9,10,11]$. Since farm income data or a productivity measure were not available for each tract in this study, the proportion of cultivated land was used as a proxy measure to reflect the income producing capacity of each tract. It was hypothesized that the price of rural land would increase as the proportion of cultivated land increased. The proportion of pastureland and woodland were also calculated as alternative variables.

Capital improvements tend to increase the value productivity of land and are usually capitalized into the price of rural land. The value of buildings is a measure of the capital improvements to each tract. It was hypothesized that the value of buildings per acre would have a positive relationship with rural land prices.

Location theory indicates a negative relationship should exist between rural land prices and distance from markets and population centers. Land rent is expected to decrease as distance from the market increases and therefore, buyers are expected to pay less for those tracts located at 
greater distances from the market. Since the nonagricultural demand for land declines as distance from a population center increases, this hypothesis applies to the nonagricultural as well as the agricultural demand for land. Locational variables were specified for each tract of land by calculating the distance to the nearest population center, four-lane highway, interstate interchange, lake, beach and Disney World. Previous studies [3, $4,5,13,18,19]$ have attempted to measure the effect of location variables on rural land prices. Several studies have estimated the effect of location as a linear relationship and in some cases found it not statistically significant $[3,4,5]$.

The per acre price of rural land is also expected to vary with the size of the tract. Smaller tracts of land may have more potential buyers and the price of smaller tracts may be bid up by buyers competing for the land for farm expansion, a rural residential site or other nonfarm use. Due to the large sums of money required to purchase large tracts, the price per acre is generally lower as the size of tract increases. It has been reported that farm real estate transfers that were smaller than 100 acres commanded about twice the price of the national average for all transfers $[17]$. It was hypothesized that a negative relationship would exist between size of tract and rural land prices. Although several studies have estimated the relationship between size of tract and the per acre price of rural land in linear models $[1,3,7,13]$, at least one study [9] reported a nonlinear relationship indicating that for each increase in total acres the price per acre declines at a decreasing rate.

The financial terms associated with land sales may affect who buys rural land, but have been reported not to be significant factors affecting rural land prices $[7]$. Therefore, variables reflecting the financial terms of the sales were not included in the model.

To estimate the effect of different factors on the price of rural land with cross-sectional data, many studies have used linear models $[1,3,4,5,7,8$, $13,19]$. Theory and other studies $[9,12]$ indicate that several of the variables included in the model in this study may have nonlinear relationships to rural land prices. The farther a tract of land is located from an urbanizing area the smaller the expected effect. Rural land prices are expected to decrease at a decreasing rate as distance from the urban area increases. Small tracts of land sell for a higher price per acre than large tracts. The per acre price of land is expected to decrease at a decreasing rate as the size of tract increases. To estimate these type of relationships nonlinear forms of the model were specified.

Least squares regression were used to estimate both linear and nonlinear forms of the model. In the linear formulations, several of the variables were not significant. In the nonlinear formulations, the reciprocal of the variables that were expected to cause rural land prices to decrease at a decreasing rate was substituted for the log of that variable to test alternative nonlinear forms.

The following specification of the model was used:

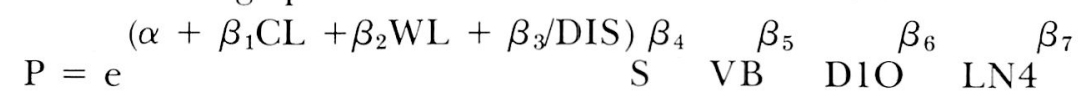


where

$\mathrm{P}=$ sale price per acre for each tract,

$\mathrm{CL}=$ proportion of tract in cultivated land,

$\mathrm{WL}=$ proportion of tract in woodland,

DIS = distance to Orlando in miles,

$\mathrm{S}=$ size of each tract in acres,

$\mathrm{VB}=$ value of buildings in dollars per acre,

$\mathrm{D} 1 \mathrm{O}=$ distance to a city between 10,000 and 50,000 in miles, and

LN4 = distance to a four-lane highway in miles.

\section{EMPIRICAL FINDINGS}

The estimated coefficients and t-values for each variable are presented in Table 1. The size of tract, distance to Orlando, distance to a city between 10,000 and 50,000 population, distance to a four-lane highway, value of buildings per acre, proportion of tract in cultivated land, and proportion of tract in woodland explained about 59 percent of the variation in rural land prices in the six-county study area.

An increase in the proportion of cultivated land in the tract results in an increase in rural land prices. The proportion of cultivated land is a proxy measure for the agricultural income producing capacity. With a 10 percent increase in the proportion of cultivated acreage, the estimated price of rural land will increase by 3.5 percent. The proportion of woodland was also a significant variable in the analysis. In an area with a relatively strong nonagricultural demand for land, the proportion of woodland is apparently measuring the desirability of land for rural homesites, recreational or other nonagricultural uses. With each increase of 10 percent in the proportion of woodland, the estimated price of rural land increases about 3.3 percent.

The distance from the tract of land to Orlando, the dominant city in the study area, was an important determinant of rural land prices in the study

Table 1. Estimated Regression Coefficients and t-values for the Analysis of Rural Land Prices in East Central Florida.

\begin{tabular}{lcc}
\hline \multicolumn{1}{c}{ Variables } & $\begin{array}{c}\text { Parameter } \\
\text { Estimate }\end{array}$ & $\begin{array}{c}t \\
\text { Statistic }\end{array}$ \\
\hline Intercept $(\alpha)$ & 8.471 & 50.37 \\
Proportion of cultivated land (CL) & .349 & 3.41 \\
Proportion of woodland (WL) & .325 & 2.79 \\
Distance to Orlando (1/DIS) & 3.959 & 4.16 \\
Size of tract (S) & -.227 & 9.12 \\
Value of buildings (VB) & .060 & 6.96 \\
Distance to city of 10.000 to & & \\
50,000 (D10) & -.056 & 1.36 \\
Distance to Four lane highway (LN4) & -.107 & 5.12 \\
\hline
\end{tabular}


area. If all variables except size are held at their means and the distance to Orlando is varied, the results indicate that as the distance increased the per acre price of rural land decreased at a decreasing rate (Figure 2). The impact of an urbanizing area becomes smaller and smaller as distance from the area increases. An additional one mile in distance at five miles from Orlando results in a $\$ 620$ decline in the estimated per acre price of rural land, a decrease of about 12 percent. The effect of distance from Orlando becomes smaller and smaller until at 20 miles away, a one-mile increase in distance results in less than one percent reduction in price.

The results indicate that as the size of tract increases the price per acre of rural land decreases. For example, a one-acre tract would be expected to sell for $\$ 7752$ while the per acre price will decrease about 50 percent for a 25 -acre tract $(\$ 3773$ per acre). For each increase in size the price per acre declines at a decreasing rate (Figure 3 ). Above 100 acres in size the per acre price for rural land becomes fairly stable and the percentage change in price due to increases in size are relatively small.

The price of rural land increases with increases in the value of buildings on a tract of land. Buyers are apparently willing to pay a higher price for land with buildings. There are relatively large increases in the price of

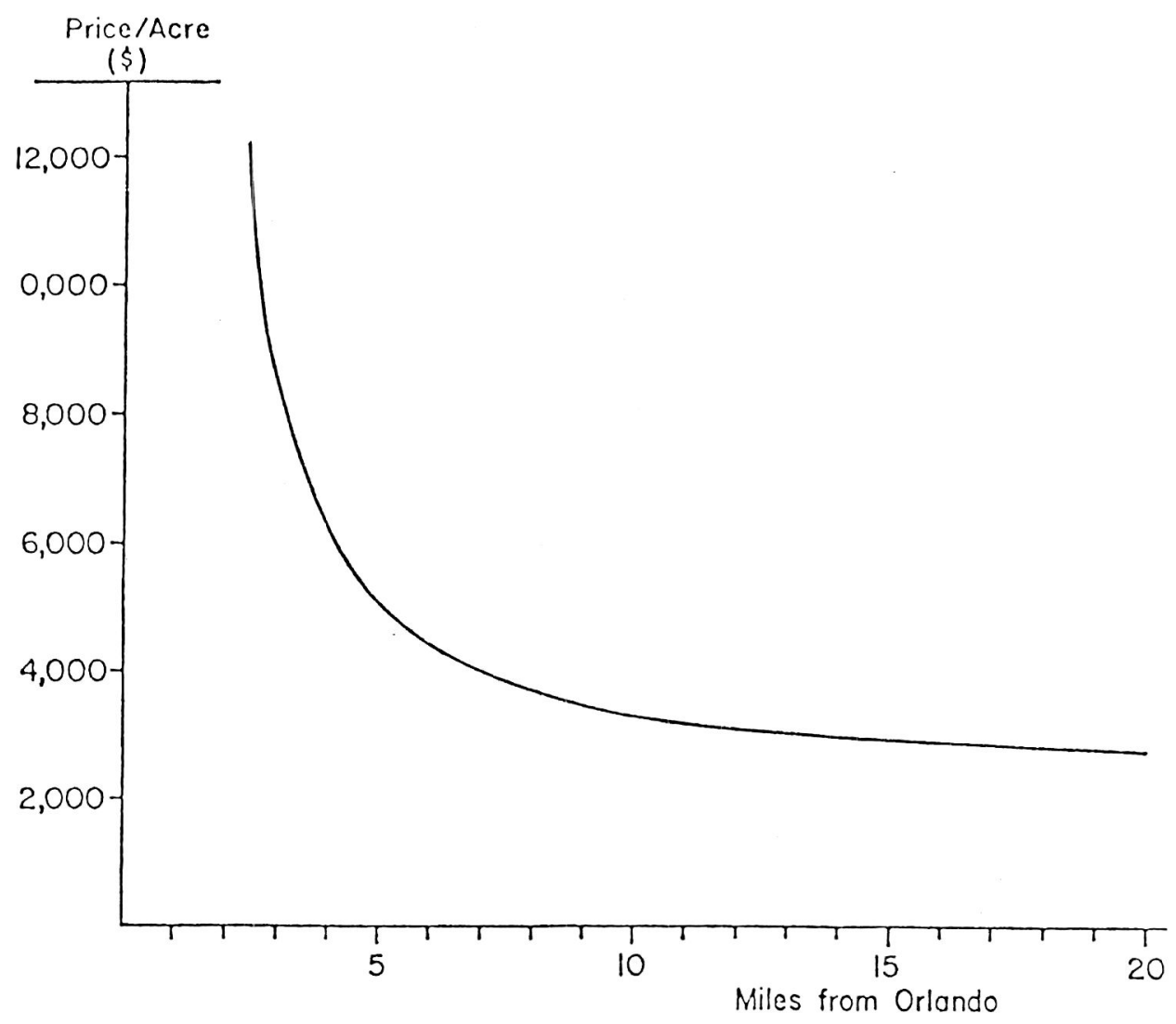

Figure 2. The effect of distance to Orlando on the price of rural land in East Central Florida. 


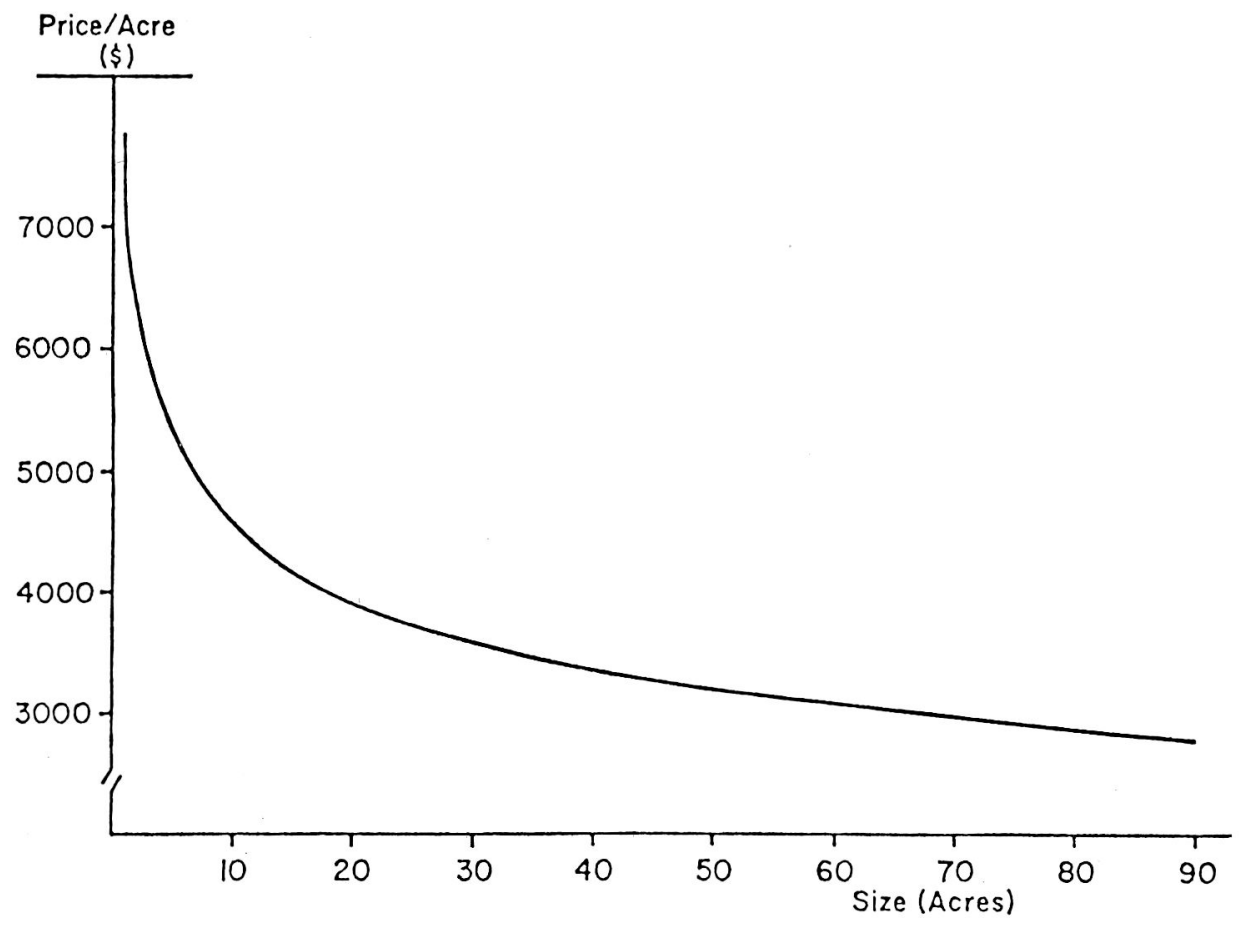

Figure 3. The effect of size of tract on the price of rural land in East Central Florida.

rural land for small increases in the value of buildings per acre. However, the increase in price per acre becomes smaller and smaller as the value of buildings increases. Beyond a building value of about $\$ 200$ per acre the price of rural land does not fully reflect the value of buildings.

The coefficient for distance to a city between 10,000 and 50,000 had the expected negative sign but was only significant at the 15 percent level. It was retained in the model because it was significant in the Lake County Model (Figure 4) and to measure the interrelationship between this variable and distance to Orlando [15]. The increase in distance from 1 mile to 2 miles resulted in a decrease in the estimated price of about 4 percent.

The distance to a four-lane highway also had a significant negative impact on rural land prices. The impact of a four-lane highway decreased at

Table 2. Estimated Regression Coefficients and t-values for the Analysis of Rural Land Prices in Orange County, Florida

\begin{tabular}{lcc}
\hline \multicolumn{1}{c}{ Variables } & $\begin{array}{c}\text { Parameter } \\
\text { Estimate }\end{array}$ & $\begin{array}{c}t \\
\text { Statistic }\end{array}$ \\
\hline Intercept $(\alpha)$ & 8.661 & 34.37 \\
Distance to Orlando (1/DIS) & 3.288 & 1.71 \\
Size of tract (S) & -.226 & 3.72 \\
Value of buildings (VB) & .072 & 5.24 \\
\hline
\end{tabular}




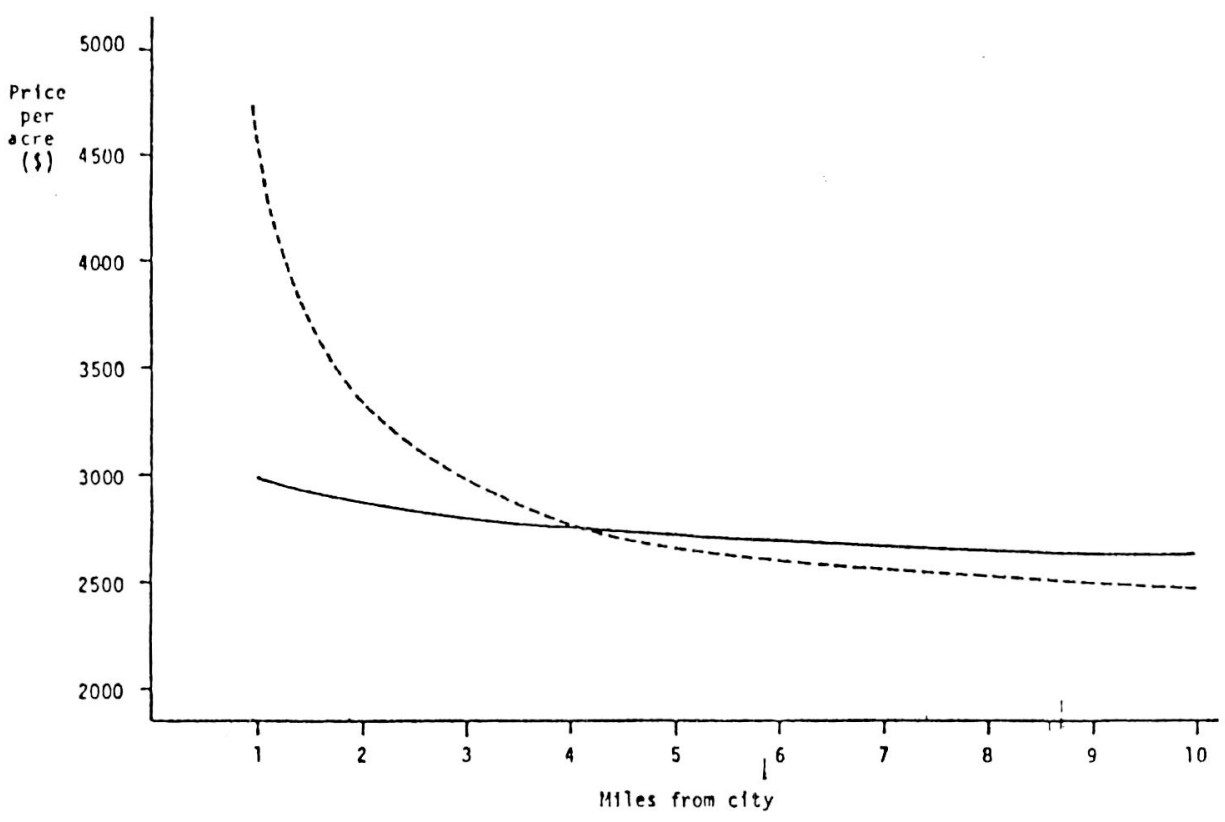

Figure 4. The effect of distance to a city between 10,000 and 50,000 on the price of rural land in the Lake County model.

a decreasing rate until only a small percentage change occurs after a distance of 5 miles. In urbanizing areas expansions in the transportation networks have made rural land more accessible to urban dwellers. Many of these people have bought land in rural areas and used the improved highways to commute to work. This increased nonagricultural demand for rural land has resulted in increased competition with agricultural users and increased prices for rural land.

To determine if the effect of these variables were different in the immediate urban area (around Orlando), the data on the sale of 63 tracts of rural land in Orange County were analyzed separately (Table 2). the land use variables, distance to a city between 10,000 and 50,000 population and distance to a four-lane highway were not significant in explaining the variation in rural land prices. Since Orange County is more urban than the rest of the six-county area and the transportation facilities are more developed, the distance to a four-lane highway was apparently not as important as it was in a more rural setting. The distance to a city between 10,000 and 50,000 population was probably not significant in Orange County because of the distance to Orlando variable. The land use variables were not significant indicating that the type of land was not important in determining the price of rural land.

The distance to Orlando was also an important determinant of rural land prices in the Orange County model. This variable displayed a similar effect to that in the All-County Model (Figure 5). As the size of tract increased the price per acre decreased at a decreasing rate similar to the effect in the All-County Model (Figure 6). However, the per acre price is 


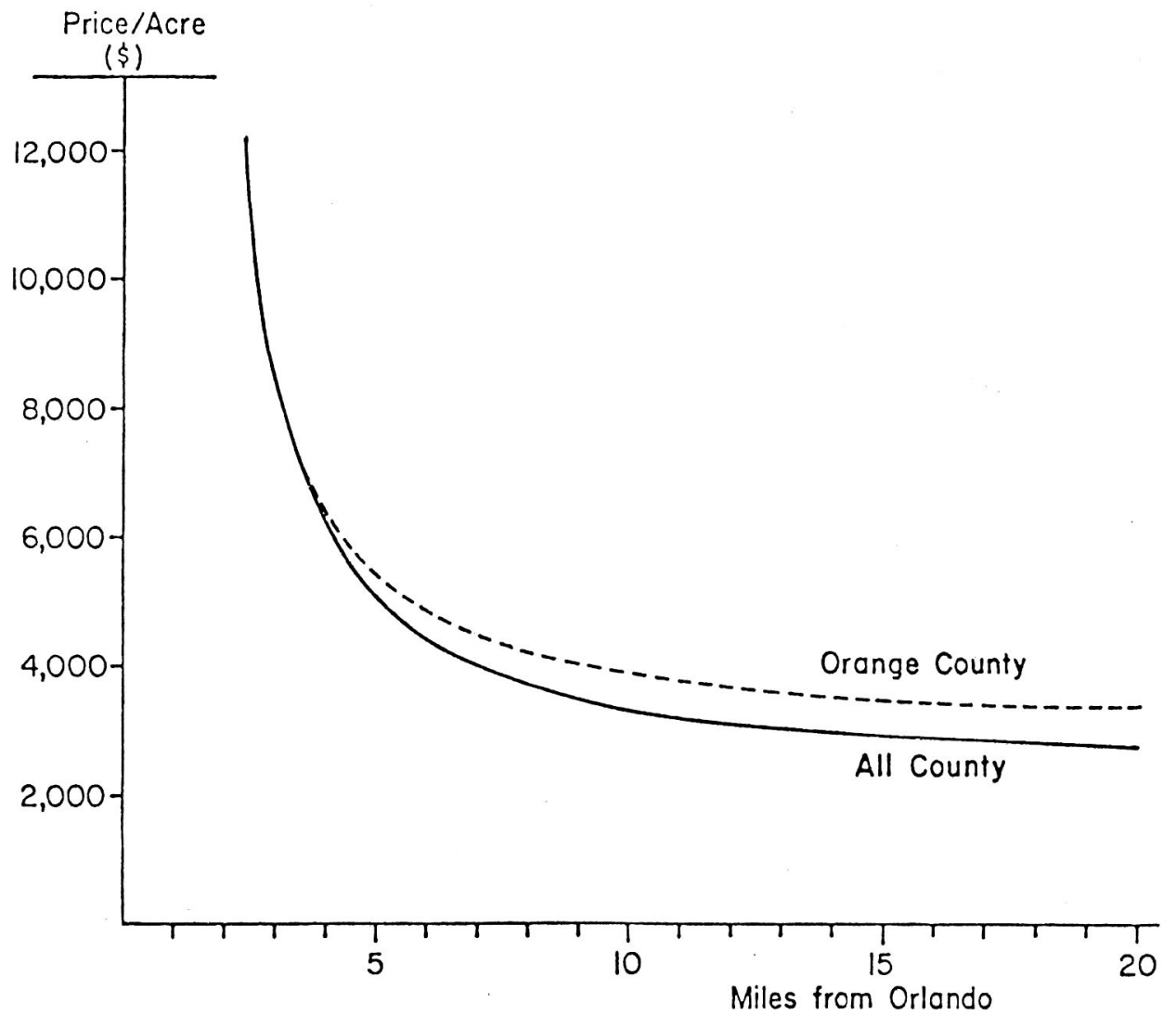

Figure 5. The effect of distance to Orlando on the price of rural land.

uniformly higher in Orange County. The nonagricultural demand for rural land in Orange County and the competition with agricultural uses has resulted in higher prices for all size of tracts. The value of buildings had a greater effect on rural land prices in Orange County than it did in other counties (Figure 7). This probably reflects the demand for homes in a more rural environment in the urbanizing area.

\section{SUMMARY AND CONCLUSIONS}

The objective of this paper was to examine the impact of physical and locational characteristics of property on rural land prices in an urbanizing area. The results support the hypothesis that location with respect to the urbanizing area and its transportation routes are important determinants of rural land prices. The nonagricultural demand for rural land near urbanizing areas has caused strong competition with agricultural uses of the land and resulted in increased prices for rural land.

The distance to the dominant city in the urbanizing area, distance to intermediate size cities, distance to four-lane highways and size of tract exhibited nonlinear negative relationships to the per acre price of rural 


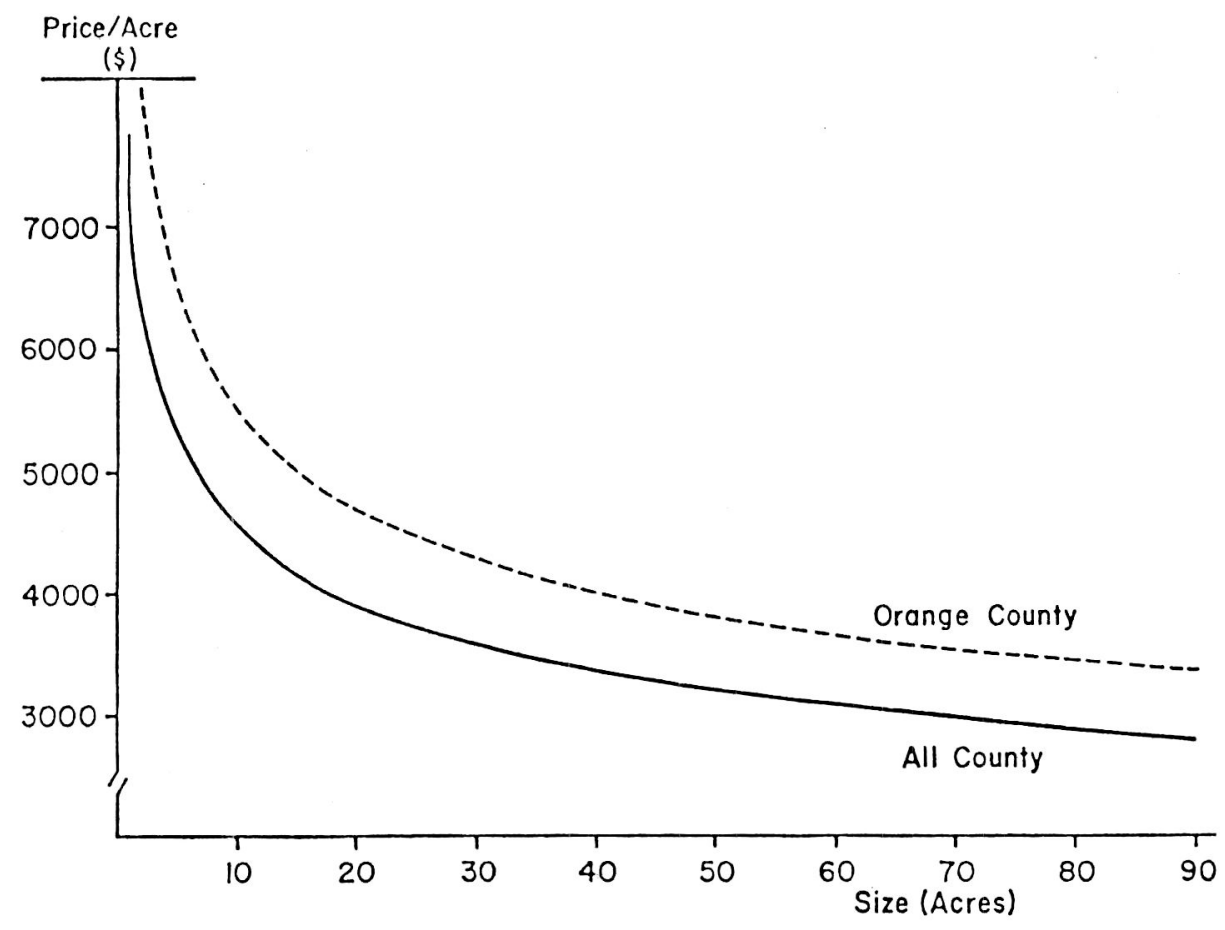

Figure 6. The effect of size of tract on the price of rural land.

land. The value of buildings and land use variables displayed nonlinear positive relationships to rural land prices. These variables explained 59 percent of the variation in rural land prices in six East Central Florida counties. An analysis of the data for Orange County, a rapidly urbanizing area, indicated that the distance to Orlando, size of tract and the value of buildings explained almost 55 percent of the variation in rural land prices. Although the percentage of variation explained was not as high as desired it is comparable to other studies that have analyzed similar data for individual tracts $[3,4,7]$. In addition to the physical and locational data available in this study, data is needed to measure the income producing capacity of the tract of land. This type of data could be in the form of a productivity index or income for past years.

Most previous studies of rural land prices have generally used linear relationships to identify and measure the impact of factors affecting rural land prices. Theory suggests that locational variables and size of tract may not be linearly related to rural land prices. The results of this study support the hypothesis of nonlinear relationships. As distance or size of tract increase in magnitude, the price per acre decreased at a decreasing rate. As the value of buildings per acre and the land use variables increased, the price per acre of rural land increased at a decreasing rate.

The results of this type of study should be useful to researchers, appraisers, lenders, policy makers, investors, and others interested in the rural land market in an urbanizing area. The direction and magnitude of the 


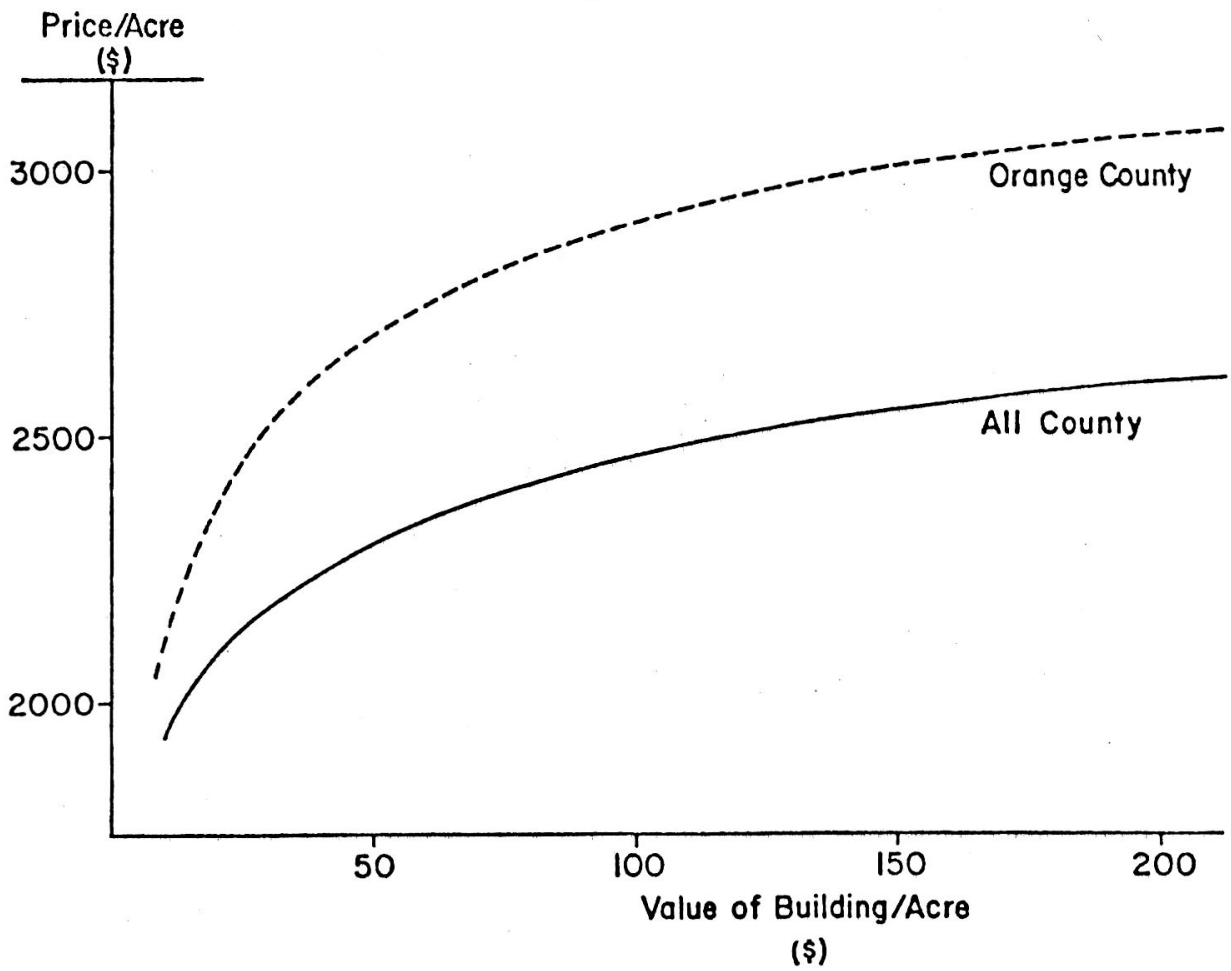

Figure 7. The effect of the value of buildings on the price of rural land.

effect of both physical and locational characteristics are important in understanding rural land prices. To some lenders and appraisers, the type of nonlinear model used in this study may appear to have little practical application. However, a table of values can easily be generated which lists the estimated price as distance and/or size of tract are varied [15].

\section{REFERENCES}

1. Blase, Melvin G. and Clyde Hesemann. "Farm Land Prices: Explainable or Illogical?" Southern Journal of Agricultural Economics, Vol. 5, No. 1:265-268. 1973.

2. Clarke, Sada L. "Farmland: An Increasingly Valuable Asset," Commodities Journal, Vol. 14, No. 4: $17-21,1979$

3. Clonts, H. A., Jr. and W. L. Gibson, Jr. Land Values in the Rural-Urban Fringe, Virginia Polytechnic Institute and State University Research Division Bulletin 58, May, 1971.

4. Craig, Robert G. and Harry P. Mapp, Jr. "The Importance of Locational Characteristics in Determining Rural Land Prices," Journal of the Northeastern Agricultural Council, Vol. 5, No. 2: 65-77. 1976.

5. Drummond, H. Evan and Fred C. White. "Determinants of Rural Property Values in Georgia," Southern Journal of Agricultural Economics, Vol. 5, No. 1: 259-264.
6. Hauschen, Larry D. and William McD. Herr. "An Analysis of Factors Affecting U.S. Farm Real Estate Values," paper presented at Southern Agricultural Economics Meetings, New Orleans, LA, February 1979.

7. Herr, William McD. "The Influence of Farm Mortgage Loan Terms on Farm Real Estate Values," Southern Journal of Agricultural Economics, Vol. 7. No. 1: 153-158.

8. Nelson, W. E. and J. L. Adrian. Variations in Rural Land Values in the Black Belt Region of Alabama, Alabama Agricultural Experiment Station Bulletin 483, November 1976.

9. Pasour, E. C., Jr. "Real Property Taxes and Farm Real Estate Values: Incidence and Implications," American Journal of Agricultural Economics 55: 549 556. 1973

10. Reynolds, John E. and John F. Timmons. Factors 
Affecting Farmland Values in the United States, Iowa Agricultural Experiment Station Research Bulletin 566. Ames, 1969.

11. Reynolds, John F. and Ron Horn Tseng. "Factors Affecting Farmland Values Among Florida Coun ties," Soil and Crop Science Society of Florida Proceedings, Vol. 29: 44-48. 1969.

12. Ruttan, Vernon W. "The Impact of Local Population Pressure on Farm Real Estate Values in California," Land Economics 37:125-131, 1961.

13. Scharlach, Wesley C. and (B. Edward Schuh. "The Land Market as a Link Between the Rural and Urban Sectors of the Economy," Journal of Farm Economirs 44: 1406-1411. 1962.

14. Thompson, Ralph B., Editor. Florida Statistical Abstract. 1978. The University of Florida Presses, Gainesville, FL, 1968

15. Tower, Devin L. "Rural Land Prices: An Empirical
Analysis in East Central Florida," M.S. Thesis, University of Florida, Gainesville, 1978.

16. U.S. Bureau of Census. 1974 Census of Agricultural State and County Data, Washington, D.C.: U.S. Government Printing Office, 1977.

17. U.S: Department of Agriculture. Farm Real Estate Market Developments, Economics, Statistics, and Cooperative Service Publication CD-84, August, 1979.

18. Vandeveer, Lonnie R. and Darrel D. Kletke. "Alternative Measures of Locational and Economic Devel. opment Factors Affecting Inter-Tract Variation of Agricultural Land Prices," paper presented at Southern Agricultural Economics Association meetings, Hot Springs, Arkansas, February, 1980

19. Wise, James O., H. Jackson Dover and Bill R. Miller Factors Affecting the Value of Rural Property in North Georgia, Georgia Agricultural Experiment Station Research Bulletin 103, February 1972. 